\title{
RESEARCH
}

Open Access

\section{Evaluation of the biological activity of Moringa oleifera leaves extract after incorporating silver nanoparticles, in vitro study}

Wafaa G. Shousha', Wael M. Aboulthana ${ }^{2^{*}}$ (D), Alaa H. Salama ${ }^{3,4}$, Mahmoud H. Saleh $^{1}$ and Ehab A. Essawy ${ }^{1}$

\begin{abstract}
Background: Moringa oleifera is rich in various active phyto-constituents (tannins, sterols, terpenoids, flavonoids, saponins, anthraquinones, alkaloids, and vitamins) in addition to different minerals in its leaves and seeds. Presence of these constituents is responsible for the antioxidant activity and the ability to protect against oxidative damage. Based on measurements of the cytotoxic activities, M. oleifera leaves were found to be more effective than the plant seeds. Therefore, the plant leaves were selected for preparation of silver plant nano-extract during the present study.

Methods: The silver nanoparticles (Ag-NPs) were synthesized then characterized by transmission electron microscope (TEM), ultraviolet-visible (UV-VIS) spectroscopy and dynamic light scattering (DLS) measurements. Moreover, the in vitro antioxidants were assayed in M. oleifera leaves extract before and after incorporating Ag-NPs through measurement of total polyphenolic compounds and scavenging activities against free radicals in addition to the cytotoxic activity against growth of human colon carcinoma. Furthermore, the phenolic compounds were detected by gas chromatography coupled with a mass spectrometer (GC/MS) and fourier transform infrared (FT-IR) spectroscopy. Also, the median lethal dose $\left(\mathrm{LD}_{50}\right)$ of the extract and nano-extract was evaluated.

Results: It was showed that incorporation of Ag-NPs into the M. oleifera leaves extract enhanced the total antioxidant capacity, concentration of total polyphenolic compounds, reducing power and scavenging activity against attack of free radicals in addition to increasing the cytotoxicity against growth of colon cancer cells. This might be related to increasing the phenolic compounds as a result of incorporation of Ag-NPs and detected by the GC/MS and FT-IR analysis. It was found that there was no wide gap in the $L_{50}$ between M. oleifera leaves extract and silver nano-extract. The $\mathrm{LD}_{50}$ values of the M. oleifera leaves extract and silver nano-extract were about 14,250 and $13,750 \mathrm{mg} / \mathrm{Kg}$, respectively.
\end{abstract}

Conclusion: The study revealed that incorporation of Ag-NPs into the M. oleifera extract enhanced the in vitro antioxidative efficiency and might be related to increasing the phenolic compounds.

Keywords: Moringa oleifera, Silver nanoparticles, Antioxidants, Polyphenols, Cytotoxicity, Scavenging activity

\footnotetext{
*Correspondence: wmkamel83@hotmail.com

${ }^{2}$ Biochemistry Department, Genetic Engineering and Biotechnology Division,

National Research Centre, P.O. 12622, 33 Bohouth St., Dokki, Giza, Egypt

Full list of author information is available at the end of the article
} 


\section{Background}

Moringa oleifera (M. oleifera) Lam. (local name Sajna) is considered as one of the trees included to the Brassica order. It belongs to the family Moringaceae which includes 13 known species of single genus (Jahn 1988; Khawaja et al. 2010).

Kasolo et al. (2010) reported that every part of M. oleifera is a storehouse of important nutrients and antinutrients in addition to presence of the minerals like calcium, potassium, zinc, magnesium, iron and copper. It has high nutritional values due to presence of different essential phytochemicals in its leaves and seeds. These phytoconstituents are represented by total phenolics, different enzymes (ascorbic acid oxidase, polyphenol oxidase, and catalase) and vitamins like vitamin C, D and E in addition to beta-carotene of vitamin $\mathrm{A}$, vitamin $\mathrm{B}$ such as folic acid, pyridoxine and nicotinic acid (Khatun et al. 2003; Mbikay 2012; Rockwood et al. 2013). Moreover, it is rich in various phytochemicals including alkaloids, steroids, tannins, flavonoids, terpenoids, saponins and anthraquinones in addition to the reducing sugars that are present along with anti-cancerous agents like glucosinolates, isothiocyanates, glycerol-1-9-octadecanoate and glycoside compounds (Berkovich et al. 2013). It was found that these substances exhibit antioxidant activity and have the ability to protect the tissues against oxidative damage (Sudha et al. 2010; Sreelatha and Padma 2011). It was demonstrated that the high content of proteins in $M$. oleifera leaves has ideal levels of essential amino acids such as methionine, cysteine, tryptophan and lysine. Therefore, it increases the availability to be absorbed in intestine and hence degradability of the nitrogen increases in the rumen comparable to soybean meal (Soliva et al. 2005).

Many previous studies have illustrated that $M$. oleifera showed potential therapeutic values including anticancer, antidiabetes, anti-rheumatoid arthritis, anti-fungal, antimicrobial (Chuang et al. 2007), anti-atherosclerotic (Chumark et al. 2008), anti-infertility, antidepressant, pain relief (Sathya et al. 2010), diuretic and thyroid regulation effects (Biswas et al. 2012). Moreover, administration of M. oleifera extracts alone lead to significant increase in hemoglobin and red blood cells as compared with control group. However, the results revealed that $M$. oleifera extract, whether provided with aluminum chloride or alone, mitigated aluminum chloride-induced anemia in albino rats (Osman et al. 2012).

Recently, it was documented that M. oleifera leaves extract attenuated brain dysfunction and brain damage (Kirisattayakul et al. 2013). It produced ameliorative effects against lead toxicity in the cerebral cortex (Owolabi et al. 2014). The recent studies were concerned with studying efficacy of the bio-active compounds isolated from $M$. oleifera leaves against activity of cancer cells with respect to tumor-suppressive activity (Budda et al. 2011; Leone et al. 2015).

Nanotechnology belongs to the most promising areas of the modern medical science. The nanomaterials are characterized by specific physical properties (shape and size) that can be improved to be applied in both fundamental and applied research field (Dhas et al. 2012).

Development of polymer-metal nanocomposites containing metal nanoparticles is considered to be one of the most promising solutions to their inherent stability problem. Incorporation of nanoparticles into polymeric matrices showed valuable properties in many practical applications (Rozenberg and Tenne 2008). Synthesis of the metal nanoparticles attracts an increasing interest due to their new and different characteristics as compared with other traditional fields (Priyadarshini et al. 2013). Synthesis of silver nanoparticles (Ag-NPs) by reduction of aqueous silver nitrate $\left(\mathrm{AgNO}_{3}\right)$ into $\mathrm{Ag}-\mathrm{NPs}$ in presence of plant extracts can be easily monitored by using UV-visible spectrophotometer. The plant extracts with Ag-NP's exhibited good antioxidant activity at lower concentrations (Johnsona et al. 2014).

The Ag-NPs have been proved to have great potential in anticancer activity. This is attributed to their efficacy to involve selectively in disruption of mitochondrial respiratory chain and consequently leads to production of reactive oxygen species (ROS) and hence interruption of adenosine triphosphate (ATP) synthesis, thereby causing nucleic acid damage (Asharani et al. 2009). Recently, it was found that incorporation of Ag-NPs into the plant extract increased the total phenolic compounds and total flavonoids. Therefore, the antioxidative and antimicrobial efficiency of the extract-loaded Ag-NPs increased and became higher than the plant extract alone or $\mathrm{AgNO}_{3}$ (Abdel-Aziz et al. 2014). The present study aimed to reveal the difference in the biological efficiency of $M$. oleifera leaves extracts before and after incorporating Ag-NPs.

\section{Materials and methods Collection of the plant material and preparation of the extracts}

Young fresh leaves and seeds of $M$. oleifera were obtained from Egyptian Scientific Society of the moringa trees, National Research Centre, Dokki, Giza, Egypt. The plant leaves and seeds were air-dried and crushed in an electric blender into powder. The extract was prepared in methanol at the concentration $10 \%(\mathrm{~W} / \mathrm{V})$ by immersing $250 \mathrm{~g}$ of the dried plant powder in $2.5 \mathrm{~L}$ of methanol in water bath at $70^{\circ} \mathrm{C}$ for $6 \mathrm{~h}$ then filtered.

\section{Synthesis of silver nanoparticles (Ag-NPs)}

In order to prepare Ag-NPs with optimum particle size and yield, several attempts were performed in order to 
obtain an easy method to reduce $\mathrm{AgNO}_{3}$ solution into Ag-NPs. In a classic method, the $\mathrm{AgNO}_{3}$ solution was left to be reduced under vigorous stirring with direct exposure to sun light and compared with Ag-NPs prepared with aid of the reducing agents $\left(\mathrm{NaBH}_{4}\right.$ or tannic acid) in presence or absence of $\mathrm{Na}$ citrate as a stabilizing agent. The yield and particle size of the obtained preparations were investigated, and the optimum method was exploited to incorporate Ag-NPs into the most effective $M$. oleifera extract that was selected based on the antioxidant and cytotoxic activities.

\section{Characterization of the synthesized Ag-NPs Transmission electron microscopy (TEM)}

The morphological and particles size of the selected AgNPs formulation were evaluated using TEM (JEOL JEM1230, Tokyo, Japan). A drop of diluted sample was placed on a copper grid and stained with $2 \%(\mathrm{w} / \mathrm{v})$ phosphotungstic acid for examination. The experiment was conducted at room temperature, and micrograph was taken at a suitable magnification power.

\section{Ultraviolet-visible (UV-VIS) spectroscopy}

Reduction of $\mathrm{AgNO}_{3}$ to silver using plant extracts was monitored by measuring UV-VIS spectrum of the reaction mixture at $\lambda 200-800 \mathrm{~nm}$ after 10 -fold dilution of the samples with deionized water. The UV-VIS spectroscopy was carried by Shimadzu UV-VIS recording spectrophotometer UV-240.

\section{Dynamic light scattering (DLS) measurements}

The synthesized Ag-NPs were investigated for their particle size by photon correlation spectroscopy (PCS) using Malvern Zetasizer Nano ZS (Malvern Instruments Ltd., Malvern, UK). Samples were diluted with double distilled water prior to analysis at room temperature with an angle of detection of $90^{\circ}$.

\section{Preparation of silver $M$. oleifera leaves nano-extract}

The extract was mixed first with $\mathrm{AgNO}_{3}$ solution, and the Ag-NPs were synthesized through reduction of $\mathrm{AgNO}_{3}$ solution with tannic acid under vigorous shaking in presence of sodium citrate as a stabilizer. The preparation was kept under vigorous stirring for 30 min until a dark gray colloidal suspension was formed indicating the successful production of Ag-NPs. The obtained preparation was centrifuged at $3000 \mathrm{rpm}$ for $15 \mathrm{~min}$. The collected $\mathrm{Ag}$-NPs were frozen at $-22^{\circ} \mathrm{C}$ then placed in a Novalyphe-NL 500 Freeze Dryer (Savant Instruments Corp., USA) with a condenser temperature of $-45^{\circ} \mathrm{C}$ and a pressure of $7 \times 10^{-2}$ mbar. The lyophilized preparations were kept in tightly closed containers at room temperature till use.
In vitro antioxidant and cytotoxic activities of the different extracts

All these measurements were assayed in different $M$. oleifera leaves and seeds extract. Also, they were assayed in the $M$. oleifera leaves extract before and after incorporation of Ag-NPs.

\section{Total polyphenolic compounds}

The total polyphenolic compounds were estimated according to the method suggested by Singleton and Rossi (1965) using folin ciocalteu reagent purchased from Sigma Chemicals Co. Concentration of the total polyphenols was calculated as a gallic acid equivalent from the calibration curve of gallic acid standard solutions covering the concentration range between 0.2 and 1.0 $\mathrm{mg} / \mathrm{ml}$.

\section{Total antioxidant capacity}

Total antioxidant capacity of the extract was evaluated through assay of the green phosphate $/ \mathrm{Mo}^{5+}$ complex according to the method described by Prieto et al. (1999). Antioxidant capacity was expressed as mg gallic acid equivalent per gram dry weight.

\section{Total reducing power}

The total reducing power was determined according to the method suggested by Oyaizu (1986). The absorbance was measured at $700 \mathrm{~nm}$ against blank prepared without adding extract. Ascorbic acid was used as standard at various concentrations. A high absorbance of the reaction mixture at $700 \mathrm{~nm}$ indicates a higher reducing power.

\section{Free radical scavenging activity $D P P H$ radical-scavenging activity}

Percentage of the antioxidant activity was evaluated by method described by Brand-Williams et al. (1995) using 2,2-diphenyl-1-picryl-hydrazyl-hydrate (DPPH) for initiation of the free radicals, and the absorbance of the resulting solution was measured spectrophotometrically at $517 \mathrm{~nm}$.

\section{ABTS radical scavenging assay}

For 2,2' -azinobis-(3- ethylbenzothiazoline-6-sulfonic acid) (ABTS) assay, the procedure followed the method suggested by Arnao et al. (2001) with some modifications. The extracts were allowed to react with ABTS solution, and the absorbance was taken at $734 \mathrm{~nm}$ after $7 \mathrm{~min}$ using a spectrophotometer. The ABTS scavenging capacity of the extract was compared with that of ascorbic acid.

\section{Anticancer activity}

Cytotoxic activity test (in vitro bioassay on human tumor cell lines) was conducted and determined. It was 
performed on human colon carcinoma cell line according to protocol suggested by Vichai and Kirtikara (2006).

\section{Chromatographic analysis of total phenolics}

The total phytoconstituents were subjected to gas chromatography coupled with a mass spectrometer (model Shimadzu GC/MS-QP5050A). The constituents have been identified by comparison of their spectral fragmentation patterns with those of the available database libraries Wiley (Wiley Int.) USA and NIST (Nat. Inst. St. Technol., USA) and/or published data (Adams 1989). The compounds were identified qualitatively based on retention time and relative abundance of three characteristic masses. The quantitative determination was carried out based on peak area integration.

\section{Fourier transform infrared (FT-IR) spectroscopy}

The FT-IR technique is used to analyze chemical composition of the organic chemicals. The FT-IR spectrum of plant extract was carried out before and after incorporating Ag-NPs to identify the possible bio molecules responsible for the capping and stabilization of nanoparticles. The FT-IR measurement was carried out to confirm increasing the phenolic compounds after incorporating Ag-NPs.

This analysis was carried out by using FT-IR technique manufactured by Bruker depending on Eaton et al. (1995). Fifty milliliters of the extract was diluted to 1000 $\mathrm{ml}$ with nanopure distilled water. One milliliter of $\mathrm{HCl}$ was added followed by $30 \mathrm{ml}$ of Freon (tri chlorotriflor$\mathrm{o}^{-}$ethane) obtained from Merck Chemical Co then shaking for $2 \mathrm{~min}$. The two immiscible layers were allowed to be separated with taking the Freon in another container. The last step repeated three times for ensuring that all the components migrated from the extract to the organic layer. The absorbance estimated against blank at the wave number $2930 \mathrm{~cm}^{-1}$ then the concentration was calculated.

\section{Experimental design Ethical statement}

The experimental design and animal handling were performed according to the experimental protocol which was approved by Institutional Animal Ethics Committee of National Research Centre, Dokki, Giza, Egypt in accordance with guidelines as per "Guide for the care and use of laboratory animal" and with permission from Committee for the Purpose of Control and Supervision of Experiments on Animals.

\section{Median lethal dose of different extracts $\left(L D_{50}\right)$}

The different $M$. oleifera extracts (before and after incorporation of Ag-NPs) were studied separately for evaluating the $\mathrm{LD}_{50}$. One hundred and sixty adult albino mice (weight $20-25 \mathrm{~g}$ ) were divided into 10 groups (8 mice in each group) for calculating the $\mathrm{LD}_{50}$ of $M$. oleifera extracts and 10 groups for that of silver M. oleifera nano-extracts. The groups were treated orally by stomach tube with rising doses of 2000, 4000, 6000, 8000, 10, $000,12,000,14,000,16,000,18,000$, and $20,000 \mathrm{mg} / \mathrm{Kg}$. Mortality was recorded after $24 \mathrm{~h}$ of extract and nanoextract treatment. The $\mathrm{LD}_{50}$ was calculated using equation suggested by Paget and Barnes (1964).

\section{$\mathrm{LD}_{50}=D \mathrm{~m}-\{\Sigma(Z . \mathrm{d}) / n\}$.}

where $\mathrm{Dm}$ is the dose by which all the mice died, $Z$ is half the sum of dead mice from two successive doses, $d$ is the difference between the two successive doses and $N$ is number of mice in each group.

\section{Results}

The Ag-NPs can be produced easily by reduction of $\mathrm{AgNO}_{3}$ solution. Among the reduction methods used is the use of vigorous shaking with the exposure of sunlight. Unfortunately, this method led to extremely low yield of Ag-NPs with large particle size (2007 nm). Thus, an additional 2 reducing agents should be used, namely; $\mathrm{NaBH}_{4}$ and tannic acid. The particle size of Ag-NPs prepared using equimolar $\mathrm{AgNO}_{3}$ and $\mathrm{NaBH}_{4}$ was significantly larger than those prepared using equimolar concentration of $\mathrm{AgNO}_{3}$ and tannic acid $(1928 \mathrm{~nm}$ and $914 \mathrm{~nm}$, respectively). In an attempt to further reduce the particle size, half of the $\mathrm{AgNO}_{3}$ amount was exchanged with tannic acid. A great decrease in the particle size was obtained $(67 \mathrm{~nm})$. Thus, this condition of $\mathrm{AgNO}_{3}$ was adopted to prepare extract loaded nanoparticles. Loading of extract into $\mathrm{AgNO}_{3}$ did not lead to a significant increase in particle size $(78.9 \mathrm{~nm}$ for the loaded nanoparticles).

The TEM is one of the most significant techniques suitable to examine structural properties of the fabricated nanomaterials. It was used to assess size, shape and morphology of nanoparticles. As illustrated in Fig. 1a, it was observed that the Ag-NPs were predominantly spherical in shape, while some of the nanoparticles were irregular in shape. No aggregations were detected. Presence of the Ag-NPs maintained homogeneity and uniformity of Ag-NPs distribution in the particles size ranged between 5 and $10 \mathrm{~nm}$.

Based on the data obtained using the UV-VIS spectroscopy which is a precise suitable and reliable method for the main characterization of manufactured nanoparticles correspondingly used to display stability and fabrication of the Ag-NPs, it was confirmed that Ag-NPs were prepared within the chemical reduction method. The Ag-NPs generate strongly interrelate with exact wavelengths of light. Also, UV-VIS spectroscopy is easy, fast, simple and discerning for various types of nanoparticles , requests simply a short period time for 


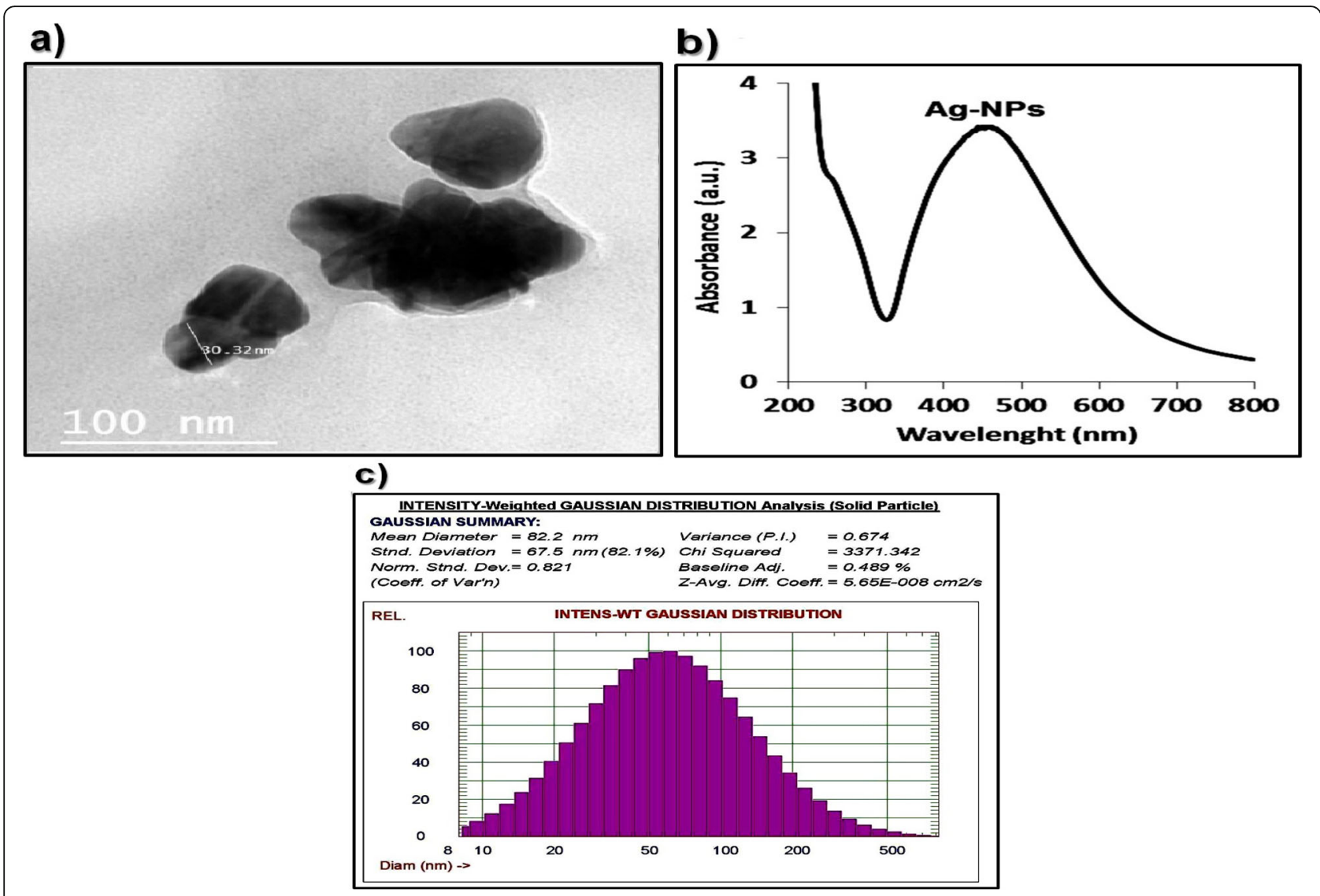

Fig. 1 a TEM image of Ag-NPs, b UV-spectroscopy of the prepared Ag-NPS, and $\mathbf{c}$ DLS of the Ag-NPS

measurement. As illustrated in Fig. 1b, the prepared AgNPs showed a sharp peak at $450 \mathrm{~nm}$ that confirms formation of the Ag-NPs. Consequently, DLS is a nondestructive technique used to acquire the average diameter of the prepared dispersed nanoparticles in aqueous solutions. It is mostly used for estimating particle size of the Ag-NPs and its distributions in the aqueous solutions. The plant extracts were effectively involved in synthesis and controlled formation of Ag-NPs.

As revealed in Table 1, it was found that the M. oleifera leaves extract found to be more effective than extract of the plant seeds. This was represented by the higher concentration of the total polyphenolic compounds, total antioxidant capacity, reducing power and free radical scavenging activity in addition to the lower extract concentration required to kill $50 \%$ of colon cancer cells.
As presented in Table 2, it was noticed that incorporation of Ag-NPs enhanced the total antioxidant capacity, concentration of total polyphenolic compounds, reducing power and scavenging activity against free radicals initiated by ABTS and DPPH in addition to increasing the cytotoxicity against growth of the colon cancer cells. Data obtained by the GC/MS analysis showed that the phenolic compounds increased as a result of incorporating Ag-NPs. As recorded in Table 3, it was noticed that 40 phenolic compounds were identified in the aqueous $M$. oleifera leaves extract before incorporating of AgNPs. It was noticed that 3-octanol, 2-butanol, and 2methyl-2-hexanol (identified at Rts 38.80, 41.88, and $56.25 \mathrm{~min}$, respectively) represent the highest percents in the extract $(8.61,34.27$, and $7.11 \%$, respectively). On the other hand, 50 phenolic compounds were identified in the silver M. oleifera leaves nano-extract (Table 4). It

Table 1 Total antioxidant capacity and free radical scavenging activity in M. oleifera leaves and seeds extracts

\begin{tabular}{lllllll}
\hline Extract & $\begin{array}{l}\text { Total antioxidant capacity } \\
(\mathrm{mg} \text { gallic acid/gm) }\end{array}$ & $\begin{array}{l}\text { Total polyphenols } \\
(\mathrm{mg} \text { gallic acid/100 } \mathrm{g})\end{array}$ & $\begin{array}{l}\text { Reducing power } \\
(\mu \mathrm{g} / \mathrm{mL})\end{array}$ & ABTS $(\mathrm{mg} / \mathrm{gm})$ & Antioxidant activity $(\%)$ & $\mathrm{C}_{50}(\mu \mathrm{g} / \mathrm{mL})$ \\
\hline Leaves & $0.12 \pm 0.007^{*}$ & $0.67 \pm 0.006^{*}$ & $0.34 \pm 0.03^{*}$ & $55.25^{*}$ & $57.8^{*}$ & $50.58^{*}$ \\
Seeds & $0.06 \pm 0.003$ & $0.04 \pm 0.003$ & $0.21 \pm 0.03$ & 25.92 & 32.2 & 82.92 \\
\hline
\end{tabular}

*The most effective extract, values expressed as mean $\pm \mathrm{SE}$ of four replicates 
Table 2 Total antioxidant capacity and free radical scavenging activity in M. oleifera leaves extracts before and after incorporating of Ag-NPs

\begin{tabular}{lllllll} 
M. oleifera leaves extract & $\begin{array}{l}\text { Total antioxidant capacity } \\
(\mathrm{mg} \text { gallic acid/gm) }\end{array}$ & $\begin{array}{l}\text { Total polyphenols } \\
(\mathrm{mg} \text { gallic acid/100 g) }\end{array}$ & $\begin{array}{l}\text { Reducing power } \\
(\mu \mathrm{g} / \mathrm{mL})\end{array}$ & $\mathrm{ABTS}(\mathrm{mg} / \mathrm{gm})$ & Antioxidant activity $(\%)$ & $I_{50}(\mu \mathrm{g} / \mathrm{mL})$ \\
\hline Before & $0.13 \pm 0.003$ & $0.72 \pm 0.056$ & $0.34 \pm 0.03$ & 55.25 & 57.8 & 50.58 \\
After & $0.60 \pm 0.04^{*}$ & $0.92 \pm 0.038^{*}$ & $5.06 \pm 0.82^{*}$ & $82.27^{*}$ & $79^{*}$ & $18.15^{*}$ \\
\hline
\end{tabular}

${ }^{*}$ The most effective extract, values expressed as mean \pm SE of four replicates

was found that 3-methyl-2,4-pentanediol, butanal and bis[(2,4,6-tritertbutylphenyl)amino] phenylchlorosilane (identified at Rts $38.82,41.87$ and $48.21 \mathrm{~min}$, respectively) represent the highest percents in the extract (6.17, 34.43 and $4.75 \%$, respectively).

As illustrated in Fig. 2 and recorded in Table 5, it was found that 7 phenolic compounds were identified in the M. oleifera leaves extract before incorporating Ag-NPs. As regard to silver $M$. oleifera leaves nano-extract, it was noticed that 17 phenolic compounds were identified as illustrated in Fig. 3 and recorded in Table 6.

The present study revealed that there was no wide gap in value of the $\mathrm{LD}_{50}$ between $M$. oleifera leaves extract and silver M. oleifera leaves nano-extract. As illustrated in Fig. 4, it was found that the $\mathrm{LD}_{50}$ values of the $M$. oleifera leaves extract and nano-extract were about 14, 250 and $13,750 \mathrm{mg} / \mathrm{Kg}$, respectively. Moreover, the therapeutic doses $\left(1 / 20 \mathrm{LD}_{50}\right)$ for both extracts were about 712.50 and 687.50 , respectively.

\section{Discussion}

The crude extracts contain complex mixtures of biologically active compounds. Some of these compounds exhibit genotoxic or antigenotoxic effects (Yumnamcha et al. 2014). Therefore, it was necessary to undergo phytochemical analysis to illustrate the potential health hazards occurred as a result of using the plant extracts for medicinal purposes.

Silver is a nontoxic inorganic agent, and it exhibits vital functions as an antiseptic due to its efficiency against about 650 types of disease causing microorganisms (Popescu et al. 2010). It is well known that utilization of plant extracts for synthesis of Ag-NPs is economic and cost effective (Allafchian et al. 2016). Recently, it was documented that silver plant nano-extracts showed wide range of possible applications. This might refer to enhancing the active phytoconstituents which exhibit antioxidant potentials and free radical scavenging activities higher than those of the crude extracts (Abdelhady and Badr 2016).

The FT-IR spectroscopy, DLS and TEM belong to the most important techniques that used widely for characterization of the synthesized nanoparticles (Aboulthana and Sayed 2018). During the current study, it was noticed that the Ag-NPs distributed in the particles size ranged between 5 and $10 \mathrm{~nm}$. This was in accordance with results of the experiment carried out by Ahmed and Ikram (2015).

It was found that the plant extracts involved effectively in synthesis of Ag-NPs. The incubation time with $\mathrm{AgNO}_{3}$ solution along with plant extract is directly proportional rate of Ag-NPs synthesis. An increase in the incubation time increased synthesis of Ag-NPs. Presence of the plant extract did not affect formation of $\mathrm{AgNO}_{3}$ into Ag ions (Lakshmanan et al. 2018). It was found that the plant extract could be used as an efficient green reducing agent for the production of nanoparticles (Subramanian et al. 2013). Therefore, use of the natural antioxidants for synthesis of the nanoparticles seems to be a good alternative which can be due to its benign composition (Ahmad and Sharma 2012). Although it is still under dispute, various biomolecules existing in aqueous plant extracts such as polyphenols, polysaccharides and proteins have been proposed to exhibit role in nanoparticles formation (Szydlowska-Czerniak et al. 2010; Shan et al. 2015). It was reported that polyphenols that are structurally characterized by presence of one or more phenol units represent a group of biologically active molecules commonly present in plants. They are considered as one of the most important classes of secondary plant metabolites which play an effective role in treatment of various chronic diseases owing to their antioxidants potentials (Queralt et al. 2015; Silberstein et al. 2016).

The current study showed that the $M$. oleifera leaves extract was more effective than the plant seeds extract. This was in accordance with the study suggested by Rahaman et al. (2017). Who reported that the $M$. oleifera leaves extract exhibited higher potential to reduce viability of the cancer cells with inclusive $50 \%$ inhibition concentration $\left(\mathrm{IC}_{50}\right)$ at each time point of the treatments more that the seeds extract. This might be attributed to the presence of functional bioactive compounds, such as phenolic acids, flavonoids, alkaloids, phytosterols, natural sugars and vitamins in addition to the minerals (Saini et al. 2016). Furthermore, it was postulated that the $M$. oleifera leaves are rich source of vitamin $\mathrm{C}$ more than lemon and orange that are considered the main source of this compound (Mbailao et al. 2014). Therefore, M. oleifera leaves were selected to be incorporated by Ag-NPs during the current study. 
Table 3 GC/MS analysis of the M. oleifera leaves extract before incorporating Ag-NPs

\begin{tabular}{|c|c|c|c|c|}
\hline Rt & $\%$ & Identified compound & $\begin{array}{l}\text { Mol. } \\
\text { weight }\end{array}$ & Formula \\
\hline 6.79 & 1.27 & (P)-N,N'-Dimethyl[1 + 1]cycloamide & 658 & $\mathrm{C}_{46} \mathrm{H}_{46} \mathrm{~N}_{2} \mathrm{O}_{2}$ \\
\hline 7.74 & 1.18 & 1,1-Dideutero-Propene & 42 & $\mathrm{C}_{3} \mathrm{H}_{4} \mathrm{D}_{2}$ \\
\hline 12.92 & 1.08 & (2-hydroxy-5,10,15,20-tetraphenylporphinato) copper (II) & 691 & $\mathrm{C}_{44} \mathrm{H}_{28} \mathrm{CuN}_{4} \mathrm{O}$ \\
\hline 13.28 & 1.22 & N-Trifluoro acetyl-serine n-butyl ester & 257 & $\mathrm{C}_{9} \mathrm{H}_{14} \mathrm{~F}_{3} \mathrm{NO}_{4}$ \\
\hline 15.27 & 0.94 & 5-Methyl-5-Dimethoxyphosphono-6,11,16,21-tetraphenyl homoporphyrin & 750 & $\mathrm{C}_{48} \mathrm{H}_{39} \mathrm{~N}_{4} \mathrm{O}_{3} \mathrm{P}$ \\
\hline 15.51 & 1.11 & Nicotinic acid adenine dinucleotide & 664 & $\mathrm{C}_{21} \mathrm{H}_{26} \mathrm{~N}_{6} \mathrm{O}_{15} \mathrm{P}_{2}$ \\
\hline 18.15 & 0.96 & 2,5,5-trimethyl-2-]6-(tosyloxy)-4,5-epoxyhexanyl[-1,3-oxane & 398 & $\mathrm{C}_{20} \mathrm{H}_{30} \mathrm{O}_{6} \mathrm{~S}$ \\
\hline 22.80 & 1.09 & Dichloro(5,10,15,20-tetraphenylporphyrinato) vanadium & 733 & $\mathrm{C}_{44} \mathrm{H}_{28} \mathrm{Cl}_{2} \mathrm{~N}_{4} \mathrm{~V}$ \\
\hline 23.72 & 1.14 & 3-Methyl-Dodecane & 184 & $\mathrm{C}_{13} \mathrm{H}_{28}$ \\
\hline 25.61 & 1.32 & Methyl 3-ethyl-2-hexenoate & 156 & $\mathrm{C}_{9} \mathrm{H}_{16} \mathrm{O}_{2}$ \\
\hline 26.47 & 1.05 & $\begin{array}{l}\text { N,N'-(1,3-Propanediyl)-bis[3',5'-di(t-butyl)-(2-hydroxybenzylidene)imine]- } \\
\text { bis (dichloroboron) }\end{array}$ & 666 & $\mathrm{C}_{33} \mathrm{H}_{48} \mathrm{~B}_{2} \mathrm{Cl}_{4} \mathrm{~N}_{2} \mathrm{O}_{2}$ \\
\hline 26.68 & 0.93 & [tetraethyl-phthalocyaninato\} iron (II) & 680 & $\mathrm{C}_{40} \mathrm{H}_{32} \mathrm{FeN}_{8}$ \\
\hline 27.96 & 0.99 & 1,7-Bis(3,5-bis (bromomethyl)phenyl)heptane & 620 & $\mathrm{C}_{23} \mathrm{H}_{28} \mathrm{Br}_{4}$ \\
\hline 28.02 & 1.01 & $\begin{array}{l}\text { 2,2'-(Buta-1,4-diyn-1,4-diyl) bis[(5,10,15,20-tetraphenylporphyrinato) zinc } \\
\text { (II)] }\end{array}$ & 1400 & $\mathrm{C}_{92} \mathrm{H}_{56} \mathrm{~N}_{8} \mathrm{Zn}_{2}$ \\
\hline 28.64 & 1.30 & N-Allyloxymethylacrylamide & 141 & $\mathrm{C}_{7} \mathrm{H}_{11} \mathrm{NO}_{2}$ \\
\hline 28.85 & 1.27 & 3,5-Dimethyl-4-oxo-4H-pyrazole-1,2-dioxide & 142 & $\mathrm{C}_{5} \mathrm{H}_{6} \mathrm{~N}_{2} \mathrm{O}_{3}$ \\
\hline 32.55 & 1.03 & Nonanal & 142 & $\mathrm{C}_{9} \mathrm{H}_{18} \mathrm{O}$ \\
\hline 33.05 & 1.10 & Hexyl pentyl ether & 172 & $\mathrm{C}_{11} \mathrm{H}_{24} \mathrm{O}$ \\
\hline 33.28 & 1.37 & 5,17-Diethoxycarbonyl-11,23-dinitro-25,26,27,28-tetrahydroxycalix[4]arene & 658 & $\mathrm{C}_{34} \mathrm{H}_{30} \mathrm{~N}_{2} \mathrm{O}_{12}$ \\
\hline 33.48 & 2.41 & 3-Amino-1-propanol & 75 & $\mathrm{C}_{3} \mathrm{H}_{9} \mathrm{NO}$ \\
\hline 33.97 & 1.10 & Dimethylamine borane & 59 & $\mathrm{C}_{2} \mathrm{H}_{10} \mathrm{BN}$ \\
\hline 35.76 & 0.93 & (2-hydroxy-5,10,15,20-tetraphenylporphinato) Copper (II) & 691 & $\mathrm{C}_{44} \mathrm{H}_{28} \mathrm{CuN}_{4} \mathrm{O}$ \\
\hline 36.42 & 1.56 & $\begin{array}{l}\text { 3-Acetoy-8-deacetoxy-N, 19-seco-22-nor-17-(1,2-oxazocyclopropan-1-yl) } \\
\text { yunaconitine }\end{array}$ & 659 & $\mathrm{C}_{34} \mathrm{H}_{45} \mathrm{NO}_{12}$ \\
\hline 37.83 & 0.92 & 3-dimethylamino-2-isopropyl-2-methyl-2-Hazirin & 140 & $\mathrm{C}_{8} \mathrm{H}_{16} \mathrm{~N}_{2}$ \\
\hline 38.80 & 8.61 & 3-Octanol & 676 & $\mathrm{C}_{41} \mathrm{H}_{40} \mathrm{O}_{9}$ \\
\hline 40.89 & 1.01 & 2-ethyl-4-methyl-1-pentanol & 130 & $\mathrm{C}_{8} \mathrm{H}_{18} \mathrm{O}$ \\
\hline 41.88 & 34.27 & 2-Butanol & 74 & $\mathrm{C}_{4} \mathrm{H}_{10} \mathrm{O}$ \\
\hline 42.38 & 2.23 & 2-Nitro-1,3-propanediol & 121 & $\mathrm{C}_{3} \mathrm{H}_{7} \mathrm{NO}_{4}$ \\
\hline 48.21 & 6.27 & 3-chloro-2-methyl-2-pentanol & 136 & $\mathrm{C}_{6} \mathrm{H}_{13} \mathrm{ClO}$ \\
\hline 49.63 & 1.34 & $\begin{array}{l}\text { [Hexacarbonylbis(æ4-N-benzyl) } \\
\text { (bis (triphenylphosphine)iminium)trirhodium] complex }\end{array}$ & 1225 & $\mathrm{C}_{56} \mathrm{H}_{44} \mathrm{~N}_{3} \mathrm{O}_{6} \mathrm{P}_{2} \mathrm{Rh}_{3}$ \\
\hline 50.44 & 1.22 & $\begin{array}{l}\text { 5,5'-Bis(3,5-di-tertbutyl-4-oxo-2,5-cyclohexadien-1-ylidene)-5,5'-dihydro-2,2'- } \\
\text { biselenophene }\end{array}$ & 668 & $\mathrm{C}_{36} \mathrm{H}_{44} \mathrm{O}_{2} \mathrm{Se}_{2}$ \\
\hline 52.42 & 1.35 & 2,4,4-Trimethyl-2-penten-1-ol & 128 & $\mathrm{C}_{8} \mathrm{H}_{16} \mathrm{O}$ \\
\hline 53.48 & 1.09 & Threo-3,4-epoxy-2-octanol & 144 & $\mathrm{C}_{8} \mathrm{H}_{16} \mathrm{O}_{2}$ \\
\hline 54.17 & 1.22 & Methylsulfinato(5,10,15,20-tetraphenylporphyrinato) iron & 747 & $\mathrm{C}_{45} \mathrm{H}_{31} \mathrm{FeN}_{4} \mathrm{O}_{2} \mathrm{~S}$ \\
\hline 54.48 & 1.12 & $\begin{array}{l}\text { 10-dimethylaminomethyl-2,8,12,18-tetramethyl-3,7,13,17-tetraethyl-21H, } \\
\text { 23H-porphin }\end{array}$ & 490 & $\mathrm{C}_{18} \mathrm{H}_{26} \mathrm{~N}_{4} \mathrm{O}_{8} \mathrm{~S}_{2}$ \\
\hline 55.33 & 1.22 & 1,3,6,8-tetrabromo-9 (4'-iodophenyl) carbazole & 681 & $\mathrm{C}_{18} \mathrm{H}_{8} \mathrm{Br}_{4} \mathrm{IN}$ \\
\hline 55.66 & 1.24 & Ethylenimine & 43 & $\mathrm{C}_{2} \mathrm{H}_{5} \mathrm{~N}$ \\
\hline 55.73 & 1.09 & n-Butyl acetate & 116 & $\mathrm{C}_{6} \mathrm{H}_{12} \mathrm{O}_{2}$ \\
\hline 56.25 & 7.11 & 2-Methyl-2-hexanol & 116 & $\mathrm{C}_{7} \mathrm{H}_{16} \mathrm{O}$ \\
\hline 56.44 & 1.32 & 5,5'-Bis[(2-trimethylsilylethynylphenyl)ethynyl]-2,2'-bipyridine & 548 & $\mathrm{C}_{36} \mathrm{H}_{32} \mathrm{~N}_{2} \mathrm{Si}_{2}$ \\
\hline
\end{tabular}

Rt Retention time 
Table 4 GC/MS analysis of the M. oleifera leaves extract after incorporating Ag-NPs

\begin{tabular}{|c|c|c|c|c|}
\hline Rt & $\%$ & Identified compound & Mol. weight & Formula \\
\hline 7.58 & 0.82 & (E)-1-(4-Morpholino-2-butenyl) cyclohexanol & 239 & $\mathrm{C}_{14} \mathrm{H}_{25} \mathrm{NO}_{2}$ \\
\hline 8.96 & 0.74 & 4-(t-butylsulfonyl)but-3-en-2-ol & 192 & $\mathrm{C}_{8} \mathrm{H}_{6} \mathrm{O}_{3} \mathrm{~S}$ \\
\hline 9.80 & 1.23 & 2,2,4-Trimethyl pentan-1,3-dioldiisobutyrate & 286 & $\mathrm{C}_{16} \mathrm{H}_{30} \mathrm{O} 4$ \\
\hline 16.23 & 0.77 & Dodecachloro-3,4-benzophenanthrene & 636 & $\mathrm{C}_{18} \mathrm{Cl}_{12}$ \\
\hline 16.86 & 1.06 & Nonanal & 142 & $\mathrm{C}_{9} \mathrm{H}_{18} \mathrm{O}$ \\
\hline 17.04 & 1.18 & $\begin{array}{l}\text { (25R)-3á-(4'-O-Benzoyl-2',3'-didehydro-2',3'-dideoxy-à,L-rhamnopyranosyloxy)-5à- } \\
\text { spirostan-2à-ol }\end{array}$ & 648 & $\mathrm{C}_{40} \mathrm{H}_{56} \mathrm{O}_{7}$ \\
\hline 17.38 & 0.74 & $\begin{array}{l}\text { N-Cyclohexyl-1,7-dipyrrolidinylperylene-3,4: } \\
\text { 9,10-tetracarboxylic acid 3,4-anhydride-9,10-imide }\end{array}$ & 611 & $\mathrm{C}_{38} \mathrm{H}_{33} \mathrm{~N}_{3} \mathrm{O}_{5}$ \\
\hline 17.55 & 1.06 & Cyclohexanol & 100 & $\mathrm{C}_{6} \mathrm{H}_{12} \mathrm{O}$ \\
\hline 18.21 & 0.80 & D4-1,1-dimethyldiborane & 56 & $\mathrm{C}_{2} \mathrm{H}_{6} \mathrm{D}_{4} \mathrm{~B}_{2}$ \\
\hline 20.51 & 1.01 & $\begin{array}{l}\text { 8-Chloro-6-(3',4'-methylenedioxyphenyl)-3,4-diphenylpyrimido }\left[4^{\prime}, 5^{\prime}: 4,5\right] \text { thieno } \\
{[2,3-c] \text { pyridazine }}\end{array}$ & 492 & $\mathrm{C}_{24} \mathrm{H}_{14} \mathrm{Cl}_{2} \mathrm{~N}_{4} \mathrm{O}_{2} \mathrm{~S}$ \\
\hline 21.66 & 0.75 & Lipo-3-episapelin A & 684 & $\mathrm{C}_{44} \mathrm{H}_{76} \mathrm{O}_{5}$ \\
\hline 21.99 & 0.76 & $\begin{array}{l}\text { Tetracarbonyl (pentamethylcyclopentadienyl)(tetraisopropylcyclopentadienyl) } \\
\text { dimolybdenium }\end{array}$ & 676 & $\mathrm{C}_{31} \mathrm{H}_{44} \mathrm{Mo}_{2} \mathrm{O}_{4}$ \\
\hline 22.97 & 1.00 & D2-1,1-propene & 42 & $\mathrm{C}_{3} \mathrm{H}_{4} \mathrm{D}_{2}$ \\
\hline 23.71 & 1.46 & (Z)-6-(N,N-Diallylamino)-2-methyl-4-hexen-3-ol & 209 & $\mathrm{C}_{13} \mathrm{H}_{23} \mathrm{NO}$ \\
\hline 24.09 & 0.78 & rac-1,1'-Bis[2,2-dimethylcyclopropane-1,3-di (benzoate)] & 618 & $\mathrm{C}_{38} \mathrm{H}_{34} \mathrm{O}_{8}$ \\
\hline 24.58 & 1.05 & $\begin{array}{l}\text { 3,5-Diphenyl-3,5 (9,10-phenanthylene)tricyclo[5.2.1.0]decane-4-one-8- } \\
\text { Exo-9-endodicarboxylic acid }\end{array}$ & 708 & $\mathrm{C}_{44} \mathrm{H}_{36} \mathrm{O}_{9}$ \\
\hline 24.90 & 0.96 & $\begin{array}{l}\text { Diethyl \{5-[(isopropyloxy)carbonyl]-5-methyl-2-phenyltetrahydro-1H-pyrrol-3yl\} } \\
\text { phosphonate }\end{array}$ & 383 & $\mathrm{C}_{19} \mathrm{H}_{30} \mathrm{NO}_{5} \mathrm{P}$ \\
\hline 27.66 & 1.05 & $\begin{array}{l}\text { 3,5-Di-t-Butyl-4-hydroxyphenylbis(1,2-dihydro-2-oxo-N-phenylcyclohepta [b] } \\
\text { pyrrol-3-yl)methane }\end{array}$ & 658 & $\mathrm{C}_{45} \mathrm{H}_{42} \mathrm{~N}_{2} \mathrm{O}_{3}$ \\
\hline 28.33 & 0.85 & $\begin{array}{l}\text { 2,4-bis(2-chloroethyl)-6,7-bis[2-methoxycarbonyl) } \\
\text { ethyl]-1,3,5-trimethylporphyrin chloride iron (III) }\end{array}$ & 737 & $\mathrm{C}_{35} \mathrm{H}_{36} \mathrm{Cl}_{3} \mathrm{FeN}_{4} \mathrm{O}_{4}$ \\
\hline 28.64 & 2.74 & Decanal & 156 & $\mathrm{C}_{10} \mathrm{H}_{20} \mathrm{O}$ \\
\hline 28.81 & 0.96 & [Tri \{Titaniumpentamethylcyclopentadienyl(æ-oxa)\}(æ-ethyl)\{N,N-diphenlamino)\}] & 793 & $\mathrm{C}_{44} \mathrm{H}_{59} \mathrm{NO}_{3} \mathrm{Ti}_{3}$ \\
\hline 28.94 & 1.04 & Hexakis(2-methylphenyl)borazine & 621 & $\mathrm{C}_{42} \mathrm{H}_{42} \mathrm{~B}_{3} \mathrm{~N}_{3}$ \\
\hline 29.63 & 1.16 & 2-O-octyl threitol & 234 & $\mathrm{C}_{12} \mathrm{H}_{26} \mathrm{O}_{4}$ \\
\hline 30.83 & 1.02 & N-Methyl-N-nitroso-6-hydroxyhexylamine & 160 & $\mathrm{C}_{7} \mathrm{H}_{16} \mathrm{~N}_{2} \mathrm{O}_{2}$ \\
\hline 31.82 & 0.84 & 2-methyl-cyclooctanone & 140 & $\mathrm{C}_{9} \mathrm{H}_{16} \mathrm{O}$ \\
\hline 33.04 & 2.01 & 1,1-Dipentyl-2-13C-ethylene & 168 & $\mathrm{C}_{12} \mathrm{H}_{24}$ \\
\hline 33.20 & 1.86 & 5,5-Dimethyl-2 (1-methylethylidene)- 1,3-dioxane-4,6-dione & 184 & $\mathrm{C}_{9} \mathrm{H}_{12} \mathrm{O}_{4}$ \\
\hline 33.49 & 2.10 & Cyclobutyl heptyl ester oxalic acid & 242 & $\mathrm{C}_{13} \mathrm{H}_{22} \mathrm{O}_{4}$ \\
\hline 33.79 & 0.99 & 1,6-Di-O-(terbutyldipheny|silyl)-2,3-O-isopropylidene-à,D-fructose & 714 & $\mathrm{C}_{41} \mathrm{H}_{54} \mathrm{O}_{7} \mathrm{Si}_{2}$ \\
\hline 33.89 & 1.17 & 2,5-Dinhexadecyl-1,4-benzenedicarboxylic acid & 614 & $\mathrm{C}_{40} \mathrm{H}_{70} \mathrm{O}_{4}$ \\
\hline 34.07 & 0.77 & $\begin{array}{l}\text { 3,5-Diphenyl-3,5-(9,10-phenanthylene)tricyclo } \\
\text { [5.2.1.0]decane-4-one-8-exo-9-endodicarboxylic acid }\end{array}$ & 708 & $\mathrm{C}_{44} \mathrm{H}_{36} \mathrm{O}_{9}$ \\
\hline 35.01 & 2.36 & 1,3-Dimethyltriazene & 73 & $\mathrm{C}_{2} \mathrm{H}_{7} \mathrm{~N}_{3}$ \\
\hline 35.58 & 1.20 & 1-Aminocyclopropanecarboxamide & 100 & $\mathrm{C}_{4} \mathrm{H}_{8} \mathrm{~N}_{2} \mathrm{O}$ \\
\hline 35.69 & 1.10 & $\begin{array}{l}\text { (2,2-Dibenzyloxy-3-nitro-5,10,15,20-tetraphenyl-2,3-dihydroporphyrinato) copper } \\
\text { (II) }\end{array}$ & 901 & $\mathrm{C}_{58} \mathrm{H}_{40} \mathrm{CuN}_{5} \mathrm{O}_{2}$ \\
\hline 36.05 & 0.80 & $\begin{array}{l}\text { 3-(4-Chlorophenyl)-4,6-dimethoxy-2-(3-(4-chlorophenyl)-4,6-dimethoxyindol-7- } \\
\text { ylmethyl)indole-2,7-dicarbaldehyde }\end{array}$ & 642 & $\mathrm{C}_{35} \mathrm{H}_{28} \mathrm{Cl}_{2} \mathrm{~N}_{2} \mathrm{O}_{6}$ \\
\hline 36.19 & 0.97 & 1,1-Dimethoxy-3-methylbutan-2-one & 146 & $\mathrm{C}_{7} \mathrm{H}_{14} \mathrm{O}_{3}$ \\
\hline 37.04 & 1.25 & 1-nitro-heptane & 145 & $\mathrm{C}_{7} \mathrm{H}_{15} \mathrm{NO}_{2}$ \\
\hline
\end{tabular}


Table 4 GC/MS analysis of the M. oleifera leaves extract after incorporating Ag-NPs (Continued)

\begin{tabular}{|c|c|c|c|c|}
\hline $\mathrm{Rt}$ & $\%$ & Identified compound & Mol. weight & Formula \\
\hline 38.12 & 2.67 & 1-Octene & 112 & $\mathrm{C}_{8} \mathrm{H}_{16}$ \\
\hline 38.23 & 1.30 & 7,8-Dioxabicyclo[4.2.2]decane & 142 & $\mathrm{C}_{8} \mathrm{H}_{14} \mathrm{O}_{2}$ \\
\hline 38.82 & 6.17 & 3-methyl-2,4-pentanediol & 118 & $\mathrm{C}_{6} \mathrm{H}_{14} \mathrm{O}_{2}$ \\
\hline 41.87 & 34.43 & Butanal & 72 & $\mathrm{C}_{4} \mathrm{H}_{8} \mathrm{O}$ \\
\hline 42.37 & 2.00 & 6-amino-hexanoic acid & 131 & $\mathrm{C}_{6} \mathrm{H}_{13} \mathrm{NO}_{2}$ \\
\hline 44.50 & 0.92 & $\begin{array}{l}\text { 2,4-Bis[2(methoxycarbonyl)ethenyl]-6,7-bis[2-(methoxycarbonyl)ethyl]- } \\
\text { 1,3,5,8-tetrmethylporphyrin }\end{array}$ & 706 & $\mathrm{C}_{40} \mathrm{H}_{42} \mathrm{~N}_{4} \mathrm{O}_{8}$ \\
\hline 44.65 & 0.93 & 4-Butoxy-1-butanol & 146 & $\mathrm{C}_{8} \mathrm{H}_{18} \mathrm{O}_{2}$ \\
\hline 45.33 & 0.81 & 5-Methyl-4-methylene-2-(phenylthio)hex-5-enonitrile & 229 & $\mathrm{C}_{14} \mathrm{H}_{15} \mathrm{NS}$ \\
\hline 45.64 & 0.92 & (2-hydroxy-5,10,15,20-tetraphenylporphinato) zinc (II) & 692 & $\mathrm{C}_{44} \mathrm{H}_{28} \mathrm{~N}_{4} \mathrm{OZn}$ \\
\hline 46.83 & 0.78 & $\begin{array}{l}\text { 2,2,4,4-tetrakis[(t-butyl)]-1,3-bis\{[(2',4',6'-triisopropyl) phenyl]mercurio\}- } \\
\text { 1,3-diphospha-2,4-disiletane }\end{array}$ & 1156 & $\mathrm{C}_{46} \mathrm{H}_{82} \mathrm{Hg}_{2} \mathrm{P}_{2} \mathrm{Si}_{2}$ \\
\hline 47.02 & 1.01 & 2,5-Dibromo-1,4-di-n-hexadecylbenzene & 682 & $\mathrm{C}_{38} \mathrm{H}_{68} \mathrm{Br}_{2}$ \\
\hline 47.53 & 0.88 & NaMonA & 692 & $\mathrm{C}_{36} \mathrm{H}_{61} \mathrm{NaO}_{11}$ \\
\hline 48.21 & 4.75 & Bis $[(2,4,6$-tritertbutylphenyl)amino]phenylchlorosilane & 660 & $\mathrm{C}_{42} \mathrm{H}_{65} \mathrm{CIN}_{2} \mathrm{Si}$ \\
\hline
\end{tabular}

Rt Retention time

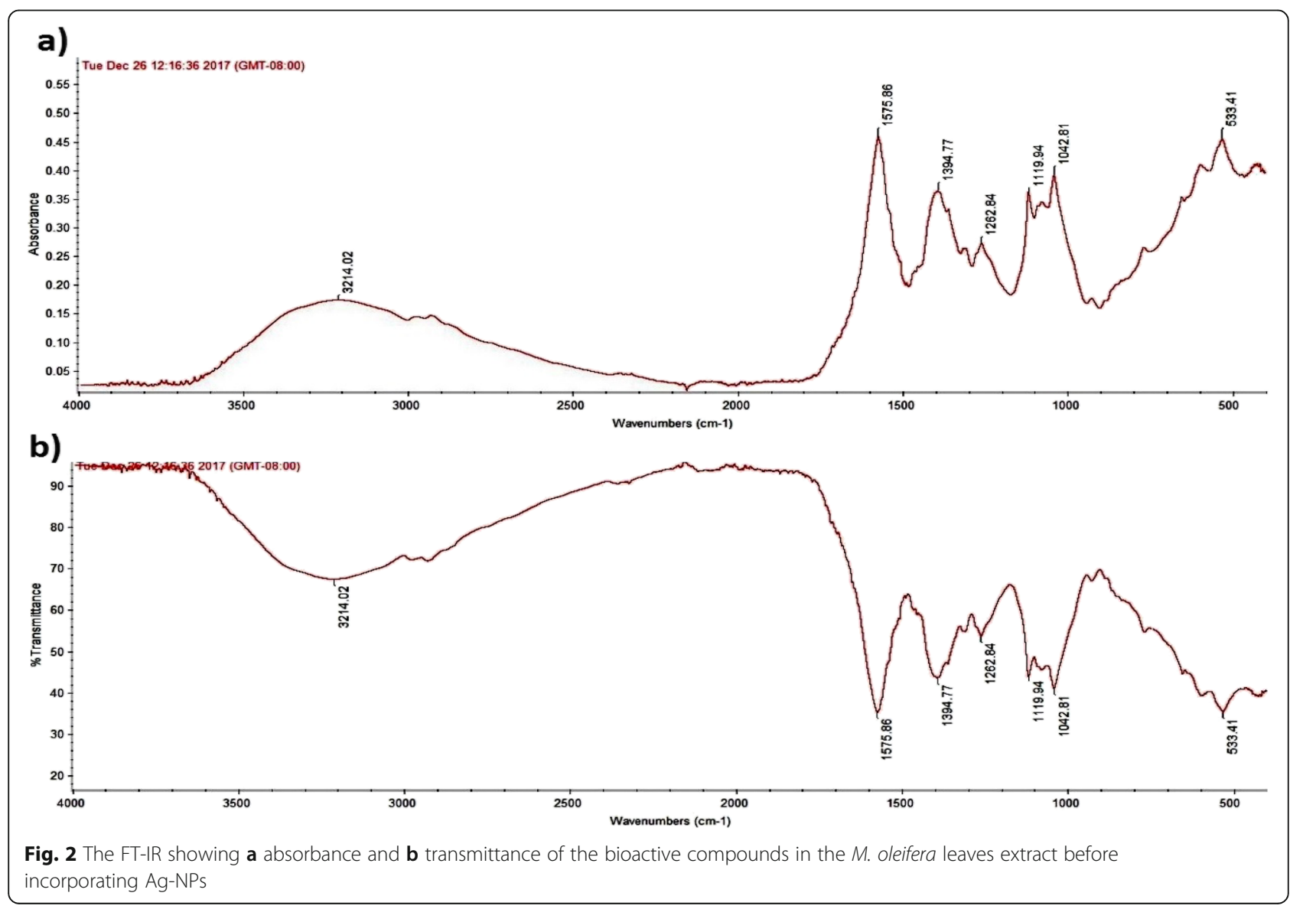


Table 5 The FT-IR measurements showing absorbance and transmittance of the bioactive compounds in the M. oleifera leaves extract before incorporating Ag-NPs

\begin{tabular}{lllll}
\hline $\begin{array}{l}\text { Wave number } \\
\left(\mathrm{Cm}^{-1}\right)\end{array}$ & Ab reading & Ab \% & Trans reading & Trans \% \\
\hline 3214.02 & 0.17 & 31.78 & 67.00 & 69.79 \\
1575.86 & 0.46 & 84.20 & 35.90 & 37.40 \\
1394.77 & 0.36 & 65.91 & 44.00 & 45.83 \\
1262.84 & 0.28 & 50.00 & 55.00 & 57.29 \\
1119.94 & 0.35 & 63.47 & 45.00 & 46.88 \\
1042.81 & 0.39 & 70.53 & 40.00 & 41.67 \\
533.41 & 0.45 & 82.38 & 36.00 & 37.50 \\
\hline
\end{tabular}

Ab Absorbance, Trans Transmittance

It was found that incorporation of Ag-NPs enhanced the total antioxidant efficiency and scavenging activity against free radicals initiated by ABTS and DPPH in addition to increasing the cytotoxicity against growth of the colon cancer cells. These findings were in accordance with Abdel-Aziz et al. (2014) and supported recently by the study carried out by Aboulthana et al. (2019) who emphasized that incorporation of Ag-NPs in the plant extract increased the active phytoconstituents (total phenolic compounds and total flavonoids). Consequently, this leads to elevating the antioxidant and

Table 6 The FT-IR measurements showing absorbance and transmittance of the bioactive compounds in the M. oleifera leaves extract after incorporating Ag-NPs

\begin{tabular}{lllll}
\hline $\begin{array}{l}\text { Wave number } \\
\left(\mathrm{Cm}^{-1}\right)\end{array}$ & Ab reading & Ab \% & Trans reading & Trans \% \\
\hline 3852.84 & 0.02 & 7.86 & 94.91 & 98.86 \\
3750.35 & 0.03 & 10.36 & 94.80 & 98.75 \\
3648.64 & 0.03 & 11.43 & 94.93 & 98.89 \\
3274.06 & 0.06 & 20.36 & 89.90 & 93.65 \\
2921.65 & 0.08 & 27.50 & 84.50 & 88.02 \\
2852.26 & 0.06 & 21.07 & 89.00 & 92.71 \\
1733.16 & 0.04 & 15.71 & 89.20 & 92.92 \\
1575.97 & 0.09 & 32.14 & 89.60 & 93.33 \\
1540.26 & 0.07 & 25.00 & 82.00 & 85.42 \\
1425.13 & 0.13 & 44.64 & 77.20 & 80.42 \\
1332.00 & 0.11 & 39.29 & 78.80 & 82.08 \\
1251.94 & 0.13 & 45.71 & 75.20 & 78.33 \\
1196.36 & 0.10 & 35.71 & 80.56 & 83.92 \\
1080.89 & 0.11 & 38.86 & 78.60 & 81.88 \\
967.09 & 0.11 & 38.25 & 80.00 & 83.33 \\
839.15 & 0.06 & 21.43 & 82.80 & 86.25 \\
612.01 & 0.21 & 74.57 & 61.50 & 64.06 \\
\hline Ab $A b s 6 a c$ & & &
\end{tabular}

Ab Absorbance, Trans Transmittance antimicrobial activity with respect to plant extract alone or $\mathrm{AgNO}_{3}$.

The FT-IR spectrum revealed presence of various active phyto-constituents including flavonoids, phenolic compounds and proteins in the aqueous $M$. oleifera leaves extract and they could be responsible for the reduction of silver ions and stabilization of the phythosynthesized Ag-NPs (Firoozi et al. 2016). Moreover, the FT-IR spectrum confirmed that incorporation of $\mathrm{Ag}$ NPs enhanced the phenolic compounds in the plant extract. Findings of the current study were in agreement with Abdelhady and Badr (2016) and supported by Aboulthana and Sayed (2018) who reported that the phenolic compounds were represented by absorbance and transmittance peaks during the FT-IR analysis. Therefore, increasing number of peaks represent increasing number of the polyphenolic compounds. Consequently, enhancement of these compounds found to be related to the total antioxidant capacity, iron reducing power, and free radicals scavenging activity and hence increasing the anticancer activity through lowering growth of the cancer cells. There is a correlation between the percentage of polyphenols consumed and the size of the produced nanoparticles (Alegria et al. 2018). Amount of the polyphenol in the extract used during formation of the nano-extract increased when size of the nanoparticles decreased. This might be attributed to conceivable regeneration of polyphenols under catalytic reaction conditions and possible interference of the small nanoparticles with measurement of the polyphenolic compounds (Mystrioti et al. 2016).

Furthermore, incorporation of Ag-NPs into the extract caused no toxicity when administrated by stomach tube. This was in accordance with the concept reported by Mohanpuria et al. (2008) and supported recently by Aboulthana and Sayed (2018) who suggested that green route synthesis of Ag-NPs found with less toxicity. This might be attributed to role of the renal excretion that represents a desirable pathway for elimination of the nanoparticles with minimal degradation rate through undergoing catabolic pathway in the body to avoid the possible side effects. Removal of the nanoparticles from the body through the renal clearance is considered as a multifaceted process involving glomerular filtration, tubular secretion and finally elimination of the molecule through urinary excretion.

\section{Conclusion}

Based on the in vitro measurements (total polyphenolic compounds, total antioxidant capacity, total reducing power, and scavenging activities against free radicals initiated by DPPH and ABTS in addition to the cytotoxic activity against growth of human colon carcinoma) that were assayed in $M$. oleifera leaves and seeds, it was 


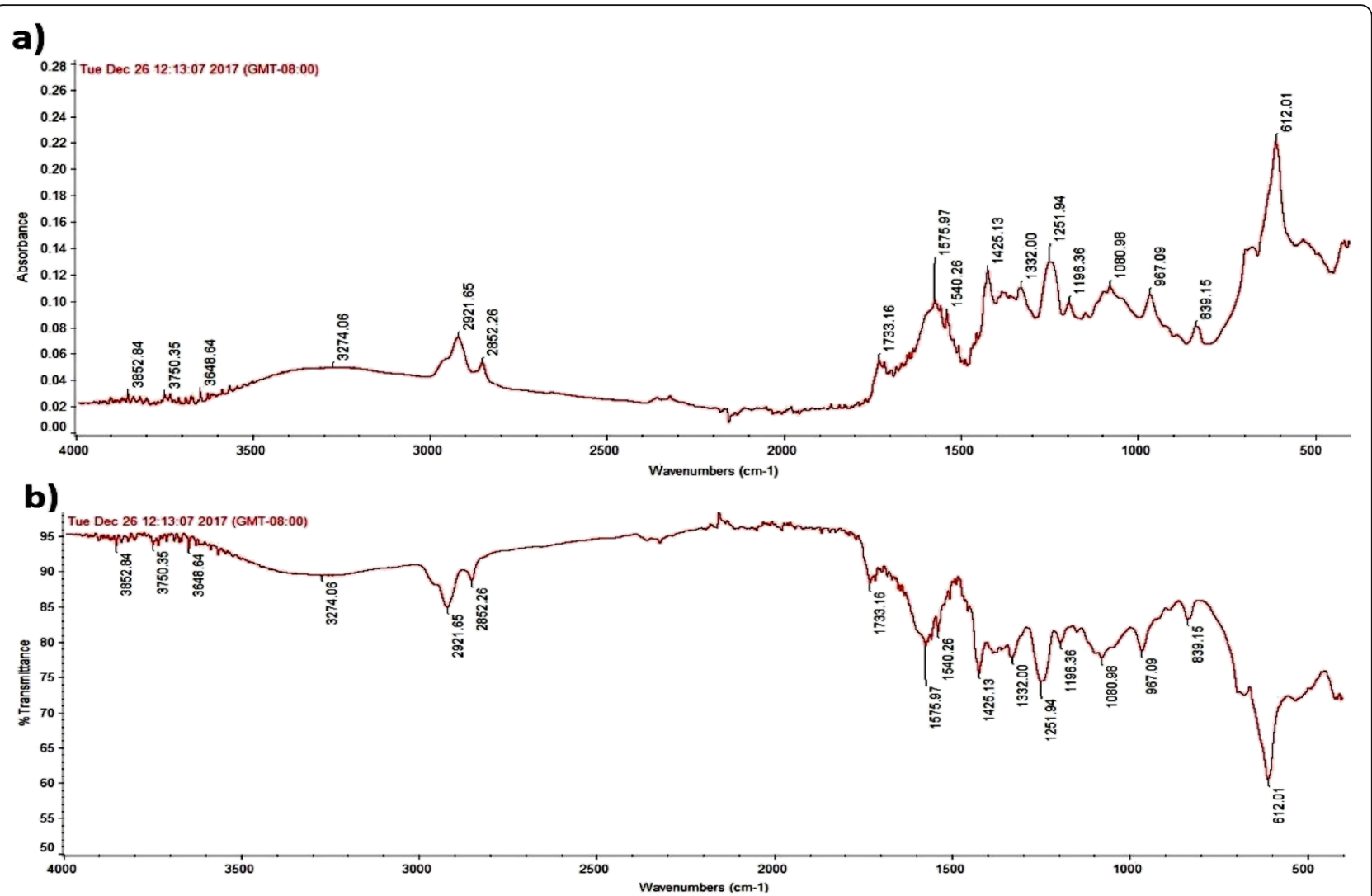

Fig. 3 The FT-IR showing a absorbance and $\mathbf{b}$ transmittance of the bioactive compounds in the M. oleifera leaves extract after incorporating Ag-NPs

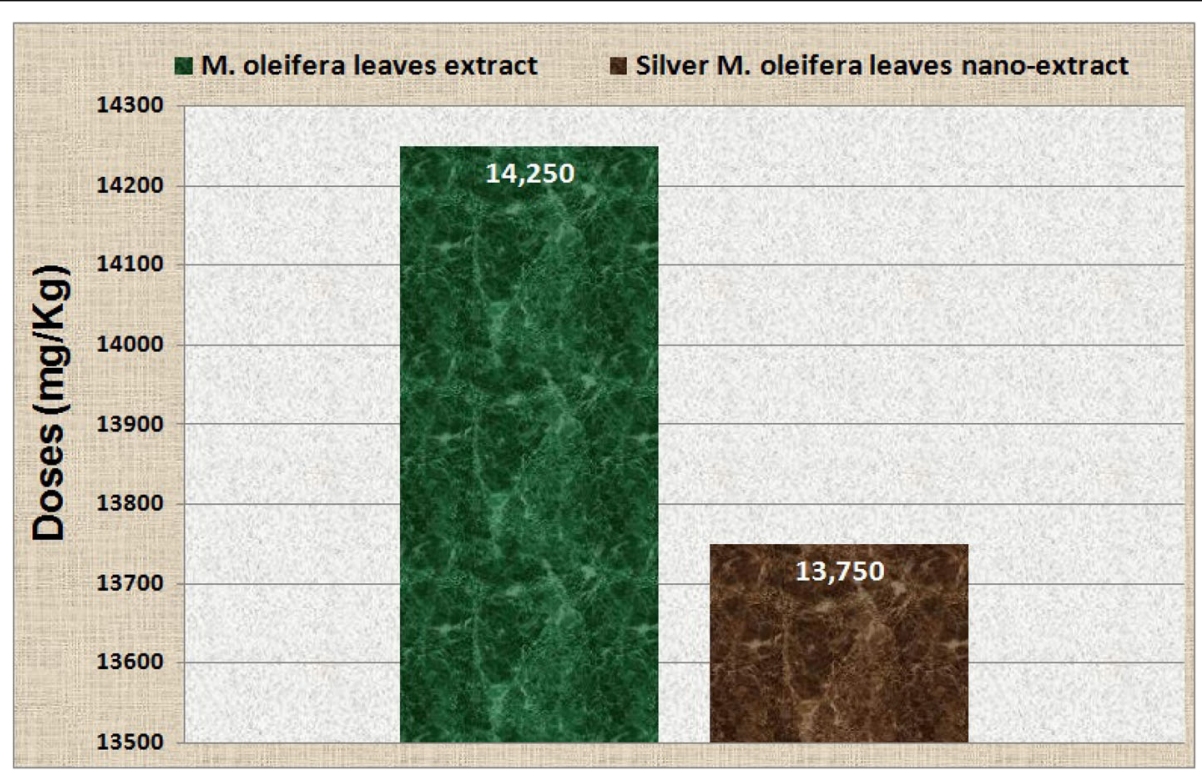

Fig. 4 The median lethal doses $\left(L_{50}\right)$ of the M. oleifera leaves extract and silver M. oleifera leaves nano-extract 
found that $M$. oleifera leaves were more effective than the plant seeds. Therefore, the plant leaves were selected for preparation of silver plant nano-extract during the present study. The Ag-NPs which were prepared to be incorporated into the $M$. oleifera leaves were characterized by TEM, UV-spectroscopy, and DLS measurements. The phenolic compounds were detected by GC/MS and FT-IR analysis. Also, the in vitro antioxidant activities were evaluated in $M$. oleifera leaves in addition to the in vivo $\mathrm{LD}_{50}$ before and after incorporating Ag-NPs.

It was found that incorporation of Ag-NPs into the $M$. oleifera leaves extract enhanced the total antioxidant capacity, concentration of total polyphenolic compounds, reducing power and scavenging activity against attach of free radicals in addition to increasing the cytotoxicity against growth of colon cancer cells. This might be related to increasing the phenolic compounds detected by the GC/MS and FT-IR analysis as a result of incorporating Ag-NPs. It was found that there was no wide gap in the $\mathrm{LD}_{50}$ between $M$. oleifera leaves extract and silver nano-extract. The $\mathrm{LD}_{50}$ values of the M. oleifera leaves extract and silver nano-extract were about 14,250 and $13,750 \mathrm{mg} / \mathrm{Kg}$, respectively.

\section{Abbreviations}

Ab: Absorbance; ABTS: 2,2'-azinobis-(3- ethylbenzothiazoline-6-sulfonic acid); Ag-NPs: Silver nanoparticles; ATP: Adenosine triphosphate; DLS: Dynamic light scattering; DPPH: 2,2-diphenyl-1-picryl-hydrazyl-hydrate; FT-IR: Fourier transform infrared; GC/MS: Gas chromatography/mass spectrometer; $I C_{50}$ : 50\% inhibition concentration; LD $D_{50}$ : Median lethal dose of different extracts; ROS: Reactive oxygen species; Rt: Retention time; SE: Standard error; TEM: Transmission electron microscope; Trans: Transmittance

\section{Authors' contributions}

All authors collected the theoretical details from the previous studies and draft the manuscript. WMA collected plant samples, performed phytochemistry studies and helped in analyzing data. WGS and MHS performed the extraction and designed the experimental model. WGS, WMA, and EAE performed the experimental work and provided reagents/materials necessary for experiments. EAE and MHS helped in writing the manuscript. AHS was responsible for preparation of the silver nano-extract and analyzing its data. WMA interpreted the analyzed data and wrote and correspond the manuscript. All authors read and approved the final manuscript.

\section{Funding}

The authors were not financially supported and they were responsible for cost of the animals and materials consumed during the study.

\section{Availability of data and materials}

The authors are ready to send the detailed scientific materials if it is useful for readings.

\section{Ethics approval and consent to participate}

The experimental design and animal handling were performed according to the experimental protocol which was approved by Institutional Animal Ethics Committee of National Research Centre, Dokki, Giza, Egypt, and were conducted in accordance with guidelines as per "Guide for the care and use of laboratory animal" and with permission from Committee for the Purpose of Control and Supervision of Experiments on Animals.

\section{Consent for publication}

Not applicable.

\section{Competing interests}

The authors have no declared conflicts of interests. They are responsible for content and writing of this article.

\section{Author details}

${ }^{1}$ Chemistry Department, Faculty of Science, Helwan University, Ain Helwan, Cairo, Egypt. ${ }^{2}$ Biochemistry Department, Genetic Engineering and

Biotechnology Division, National Research Centre, P.O. 12622, 33 Bohouth St., Dokki, Giza, Egypt. ${ }^{3}$ Pharmaceutical Technology Department, Pharmaceutical and Drug Industries Research Division, National Research Centre, P.O. 12622, 33 Bohouth St., Dokki, Giza, Egypt. ${ }^{4}$ Department of Pharmaceutics, Faculty of Pharmacy, Ahram Canadian University, 6th of October City, Cairo, Egypt.

Received: 30 July 2019 Accepted: 25 October 2019

Published online: 30 December 2019

\section{References}

Abdel-Aziz MS, Shaheen MS, El-Nekeety AA, Abdel-Wahhab MA (2014) Antioxidant and antibacterial activity of silver nanoparticles biosynthesized using Chenopodium murale leaf extract. J Saudi Chem Soc 18:356-363

Abdelhady NM, Badr KA (2016) Comparative study of phenolic content, antioxidant potentials and cytotoxic activity of the crude and green synthesized silver nanoparticles' extracts of two Phlomis species growing in Egypt. J Pharmacognosy Phytochem 5(6):377-383

Aboulthana WM, Sayed HH (2018) How to use green technology to enhance antioxidant efficiency of plant extracts: a novel strategy. J Appl Pharm 10(2): 264-267

Aboulthana WM, Youssef AM, El-Feky AM, Ibrahim NE, Seif MM, Hassan AK (2019) Evaluation of Antioxidant Efficiency of Croton tiglium L. Seeds Extracts after Incorporating Silver Nanoparticles. Egypt J Chem 62(2):181-200.

Adams P (1989) Identification of essential oils by ion trap mass spectroscopy. Academic Press, INC, New York

Ahmad N, Sharma S (2012) Green synthesis of silver nanoparticles using extracts of Anana comosus. Green Sustain Chem 2:141-147

Ahmed S, Ikram S (2015) Synthesis of gold nanoparticles using plant extract: an overview. Nano Res Appl 1:1-64

Alegria ECBA, Ribeiro APC, Mendes M, Ferraria AM, do Rego AMB, Pombeiro AJL (2018) Effect of phenolic compounds on the synthesis of gold nanoparticles and its catalytic activity in the reduction of nitro compounds. Nanomaterials (Basel) 8(5):320

Allafchian AR, Zare MSZ, Jalali SAH, Hashemi SS, Vahabi MR (2016) Green synthesis of silver nanoparticles using Phlomis leaf extract and investigation of their antibacterial activity. J Nanostruct Chem 6:129-135

Arnao MB, Cano A, Acosta M (2001) The hydrophilic and lipophilic contribution to total antioxidant activity. Food Chem 73:239-244

Asharani PV, Hande MP, Valiyaveettil S (2009) Anti-proliferative activity of silver nanoparticles. BMC Cell Biol 10:65

Berkovich L, Earon G, Ron I, Rimmon A, Vexler A, Lev-Ari S (2013) Moringa oleifera aqueous leaf extract down-regulates nuclear factor-kappa band increases cytotoxic effect of chemotherapy in pancreatic cancer cells. BMC Complement Altern Med 13:212-219

Biswas SK, Chowdhury A, Das J, Roy A, Hosen SMZ (2012) Pharmacological potentials of Moringa oleifera Lam.: a review. Int J Pharm Sci Res 3(2):305-310

Brand-Williams W, Cuvelier ME, Berset C (1995) Use of a free radical method to evaluate antioxidant activity. Lebenson Wiss Technol 28:25-30

Budda S, Butryee C, Tuntipopipat S, Rungsipipat A, Wangnaithum S, Lee JS, Kupradinun P (2011) Suppressive effects of Moringa oleifera lam pod against mouse colon carcinogenesis induced by azoxymethane and dextran sodium sulfate. Asian Pac J Cancer Prev 12(12):3221-3228

Chuang P-H, Lee C-W, Chou J-Y, Murugan M, Shieh B-J, Chen H-M (2007) Antifungal activity of crude extracts and essential oil of Moringa oleifera Lam. Bioresour Technol 98(1):232-236

Chumark P, Khunawat P, Sanvarinda Y, Phornchirasilp S, Morales NP, PhivthongNgam L, Ratanachamnong P, Srisawat S, Pongrapeeporn KU (2008) The in vitro and ex vivo antioxidant properties, hypolipidaemic and antiatherosclerotic activities of water extract of Moringa oleifera Lam. leaves. J Ethnopharmacol 116(3):439-446

Dhas TS, Kumar VG, Abraham LS, Karthick V, Govindaraju K (2012) Sargassum myriocystum mediated biosynthesis of gold nanoparticles. Spectrochim Acta A Mol Biomol Spectrosc 99:97-101 
Eaton AD, Clesceri LS, Greenberg AE (1995) $19^{\text {th }}$ edition. Standard methods for the examination of water and waste water. Method 6410 B:6-84

Firoozi S, Jamzad M, Yari M (2016) Biologically synthesized silver nanoparticles by aqueous extract of Satureja intermedia C.A. Mey and the evaluation of total phenolic and flavonoid contents and antioxidant activity. J Nanostruct Chem 6:357-364

Jahn SA (1988) Using Moringa seeds as coagulant in developing countries. J Am Works Assoc 80:43-50

Johnsona AS, Obota IB, Ukponga US (2014) Green synthesis of silver nanoparticles using Artemisia annua and Sida acuta leaves extract and their antimicrobial, antioxidant and corrosion inhibition potentials. $J$ Mater Environ Sci 5(3):899-906

Kasolo JN, Bimenya GS, Ojok L, Ochieng J, Ogwal-okeng JW (2010) Phytochemicals and uses of Moringa oleifera leaves in Ugandan rural communities. J Med Plants Res 4:753-757

Khatun S, Absar N, Ashraduzzaman M (2003) Changes in physico-chemical compositions and activities of some hydrolytic and oxidative enzymes in the two types of sajna (Moringa oleifera Lam.) leaves at different maturity levels. Indian J Plant Physiol 8(1):6-11

Khawaja TM, Tahira M, Ikram UK (2010) Moringa oleifera: a natural gift - a review. J Pharm Sci Res 2:775-781

Kirisattayakul W, Wattanathorn J, Tong-Un T, Muchimapura S, Wannanon P, Jittiwat J (2013) Cerebroprotective effect of against focal ischemic stroke induced by middle cerebral artery occlusion. Hindawi Publishing Corporation, Oxid Med Cell Longev, 2013, 951415, 10

Lakshmanan G, Sathiyaseelan A, Kalaichelvan PT, Murugesan K (2018) Plantmediated synthesis of silver nanoparticles using fruit extract of Cleome viscosa L.: assessment of their antibacterial and anticancer activity. Karbala Int J Mod Sci 4(1):61-68

Leone A, Spada A, Battezzati A, Schiraldi A, Aristil J, Bertoli S (2015) Cultivation, genetic, ethnopharmacology, phytochemistry and pharmacology of Moringa oleifera leaves: an overview. Int J Mol Sci 16(6):12791-12835

Mbailao M, Mianpereum T, Albert N (2014) Proximal and elemental composition of Moringa oleifera (Lam) leaves from three regions of Chad. J Food Resour Sci 3(1):12-20

Mbikay M (2012) Therapeutic potential of Moringa oleifera leaves in chronichyper glycemia and dyslipidemia: a review. Front Pharmacol 3:1-12

Mohanpuria P, Rana NK, Yadav SK (2008) Biosynthesis of nanoparticles: technological concepts and future applications. J Nanopart Res 10(3):507-517

Mystrioti C, Xanthopoulou TD, Tsakiridis PE, Papassiopi N, Xenidis A (2016) Comparative evaluation of five plant extracts and juices for nanoiron synthesis and application for hexavalent chromium reduction. Sci Total Environ 539:105-113

Osman HM, Shayoub ME, Babiker EM, Osman B, Elhassan AM (2012) Effect of ethanolic leaf extract of Moringa oleifera on aluminum-induced anemia in white albino rats. Jordan J Biol Sci 5:255-260

Owolabi J, William F, Olanrewaju J, Etibor T, Fabiyi O (2014) Histomorphological evidences of Moringa oleifera's ameliorative effects against lead toxicity in cerebral cortex. World J Life Sci Med Res 3(2):53

Oyaizu M (1986) Studies on product of browning reaction prepared from glucose amine. Jpn J Nutr 44:307-315

Paget GE, Barnes JM (1964) Toxicity tests. In: Laurance DR, Bacharach AL (eds) Evaluation of drug activities: pharmacometrics, vol 1. Academic Press, New York, pp 135-165

Popescu M, Velea A, Lorinczi A (2010) Biogenic production of nanoparticles. Dig J Nanomat Bios 5(4):1035-1040

Prieto P, Pineda M, Aguilar M (1999) Spectrophotometric quantitation of antioxidant capacity through the formation of a phosphomolybdenum complex: specific application to the determination of vitamin E. Anal Biochem 269:337-341

Priyadarshini S, Gopinath V, Priyadharsshini NM, MubarakAli D, Velusamy P (2013) Synthesis of anisotropic silver nanoparticles using novel strain, bacillus. Flexus and its biomedical application. Colloids Surf B Biointerfaces 102:232-237

Queralt A, Regueiro J, Alvarenga JF, Huelamo M, Leal L, Raventos M (2015) Characterization of the phenolic and antioxidant profiles of selected culinary herbs and spices: caraway, turmeric, dill, marjoram and nutmeg. Food Sci Tech 35(1):189-195

Rahaman MHA, Kadir NHA, Amin NM, Omar WBW (2017) Cytotoxicity effect of water extracts of Moringa oleifera leaves and seeds against MCF-7 cells. Acta Hortic 1158: I International Symposium on Moringa:279-286

Rockwood JL, Anderson BG, Casamatta DA (2013) Potential uses of Moringa oleifera and an examination of antibiotic efficacy conferred by M. oleifera seed and leaf extracts using crude extraction techniques available to underserved indigenous populations. Int J Phytothearpy Res 3:61-71

Rozenberg BA, Tenne R (2008) Polymer-assisted fabrication of nanoparticles and nanocomposites. Prog Polym Sci 33(1):40-112

Saini RK, Sivanesan I, Keum Y (2016) Phytochemicals of Moringa oleifera: a review of their nutritional, therapeutic and industrial significance. 3 Biotech 6(2):2032016

Sathya TN, Aadarsh P, Deepa V, Murthy PB (2010) Moringa oleifera Lam. Leaves prevent cyclophosphamideinduced micronucleus and DNA damage in mice. Int J Phytomedicine 2(2):147-154

Shan B, Yizhong Z, Sun M, Corke H (2015) Antioxidant capacity of 26 spice extracts and characterization of their phenolic constituents. J Agric Food Chem 53:7749-7759

Silberstein T, Vardi I, Harlev A, Friger M, Hamou B, Barac T (2016) Antioxidants and polyphenols: concentrations and relation to male infertility and treatment success. Oxid Med Cell Longev, 2016, 9140925, 5

Singleton VL, Rossi JA (1965) Colorimetry of total phenolics with phosphomolybdic phosphotungstic acid reagents. Am J Enol Vitic 16(3):144-158

Soliva CR, Kreuzer M, Foid N, Foid G (2005) Feeding value of whole and extracted Moringa oleifera leaves for ruminants and their effects on ruminal fermentation in vitro. Anim Feed Sci Technol 118(1-2):47-62

Sreelatha S, Padma PR (2011) Modulatory effects of Moringa oleifera extracts against hydrogen peroxide-induced cytotoxicity and oxidative damage. Hum Exp Toxicol 30(9):1359-1368

Subramanian R, Subbramaniyan P, Raj V (2013) Antioxidant activity of the stem bark of Shorea roxburghii and its silver reducing power. Springer Plus 2:28

Sudha P, Asdaq SMB, Dhamingi SS, Chandrakala GK (2010) Immunomodulatory activity of methanolic leaf extract of Moringa oleifera in animals. Indian J Physiol Pharmacol 54(2):133-140

Szydlowska-Czerniak A, Amarowicz R, Szlyk E (2010) Antioxidant capacity of rapeseed meal and rapeseed oils enriched with meal extract. Eur J Lipid Sc Technol 112:750-760

Vichai V, Kirtikara K (2006) Sulforhodamine B colorimetric assay for cytotoxicity screening. Nat Protoc 1(3):1112-1116

Yumnamcha T, Nongthomba U, Devi MD (2014) Phytochemical screening and evaluation of genotoxicity and acute toxicity of aqueous extract of Croton tiglium L. Int J Sci Res Publ 4(1):1-5

\section{Publisher's Note}

Springer Nature remains neutral with regard to jurisdictional claims in published maps and institutional affiliations.

\section{Submit your manuscript to a SpringerOpen ${ }^{\circ}$ journal and benefit from:}

- Convenient online submission

- Rigorous peer review

- Open access: articles freely available online

- High visibility within the field

- Retaining the copyright to your article

Submit your next manuscript at $>$ springeropen.com 